\title{
Feasibilities for silicon recovery from solar cells waste by treatment with nitric acid
}

\author{
Agnè Šleiniūté ${ }^{1}$, \\ Liucija Urbelyte் ${ }^{1}$, \\ Julius Denafas ${ }^{2}$, \\ Arina Kosheleva ${ }^{3}$, \\ Gintaras Denafas $^{1^{*}}$ \\ ${ }^{1}$ Department of Environmental Technology, \\ Faculty of Chemical Technology, \\ Kaunas University of Technology, \\ 19 Radvilènu Road, \\ 50524 Kaunas, Lithuania \\ ${ }^{2}$ Office of Resource Efficiency Management \\ and Cleaner Production, \\ Institute of Environmental Engineering, \\ Kaunas University of Technology, \\ 50 Gedimino Street, \\ 44239 Kaunas, Lithuania \\ ${ }^{3}$ Research Group 'Waste Resources Management', \\ Institute of Environmental Technology \\ and Energy Economics, \\ Hamburg University of Technology, \\ 40 Eissendorfer Street, \\ Hamburg, Germany
}

The feasibilities of silicon recovering from solar cell waste (SCW) by treatment with nitric acid at its concentrations of $1,2,3$ and $4 \mathrm{M}$ were investigated. The research results have shown that complete leaching of aluminum from the silicon matrix is not possible. It can be explained by formation of aluminum compounds with oxygen and silicon on the aluminum particles. Total silver leaching is achieved at maximal $4 \mathrm{M}$ concentrations of nitric acid. The influence of nitric acid concentrations on the leaching efficiency of these metals is significantly reduced at higher temperatures (up to $50^{\circ} \mathrm{C}$ ). Higher metal leaching efficiency is characteristic of larger SCA particles under more favourable spatial conditions for penetration of nitric acid ions.

Keywords: solar cells waste, silicon, aluminum, silver, treatment by nitric acid, leaching efficiency, diffusion

\section{INTRODUCTION}

Photovoltaic (PV) cells are the most popular solar cells on the market and also provide the highest energy conversion efficiencies of all commercial solar cells and modules. The cumulative global photovoltaic (PV) manufacturing capacity has been reported to be about $140 \mathrm{GW}$ by end of 2018 [1].

\footnotetext{
* Corresponding author. Email: gintaras.denafas@ktu.lt
}

This allowed for the first time in the history of solar industry to reach $0.5 \mathrm{TW}$ of installed power. It is estimated that until 2023 additional 500-700 GW will be installed globally. In parallel, the cost of solar modules and price of electricity generated by photovoltaic devices has dropped more than 5 times since 2011 [2].

There is no doubt that PV technology offers an economic and environmentally friendly way to generate power. On the other hand, solar cells and 
modules reach their end-of-life phase at some point (typically after 25-30 years of operation) and become waste, which requires decommissioning including dismantling, recycling and disposal. It has been estimated that by 2050 there will be between 60-78 metric tons of PV waste available annually [3]. Majority of these wastes will be based on crystalline silicon technology which occupies more than $90 \%$ of PV market these days. A typical structure of silicon-based solar module is given below (Fig. 1).

Front sheet is typically a solar grade glass, coated or uncoated. It can also be flat or textured. Encapsulant material is ethylene-vinyl acetate (EVA) or polyethylene oxide (POE), which are the main two types of materials used these days in PV industry. Backsheet can be a polymeric backsheet or a second sheet of glass as well. Cell interconnects are made of tin/lead coated cooper ribbons and the most important element is solar cells.
As seen in Fig. 2, a solar cell is made of silicon, aluminum and silver. Base material is silicon, which is typically boron doped, therefore it is marked as p-type silicon. On the front side, a solar cell has an antireflective layer, $n+$ emitter region and silver contacts. On the rear side, there is the full area aluminum contact and $\mathrm{p}+$ doped region called back surface field (BSF). The function of the front and rear metallization is to conduct charge carriers from the solar cell into the cell interconnects (ribbons) [4].

The growing volume of solar cell and module waste presents not only a new environmental challenge, but also new business opportunities. In order to increase the recycling ratio of $\mathrm{PV}$ modules, it is important to be able to extract not only $\mathrm{Al}$ frame, glass and cables, but also materials like silicon, silver and aluminum, and provide opportunities to re-use them again in manufacturing of photovoltaic devices or other industries as well.

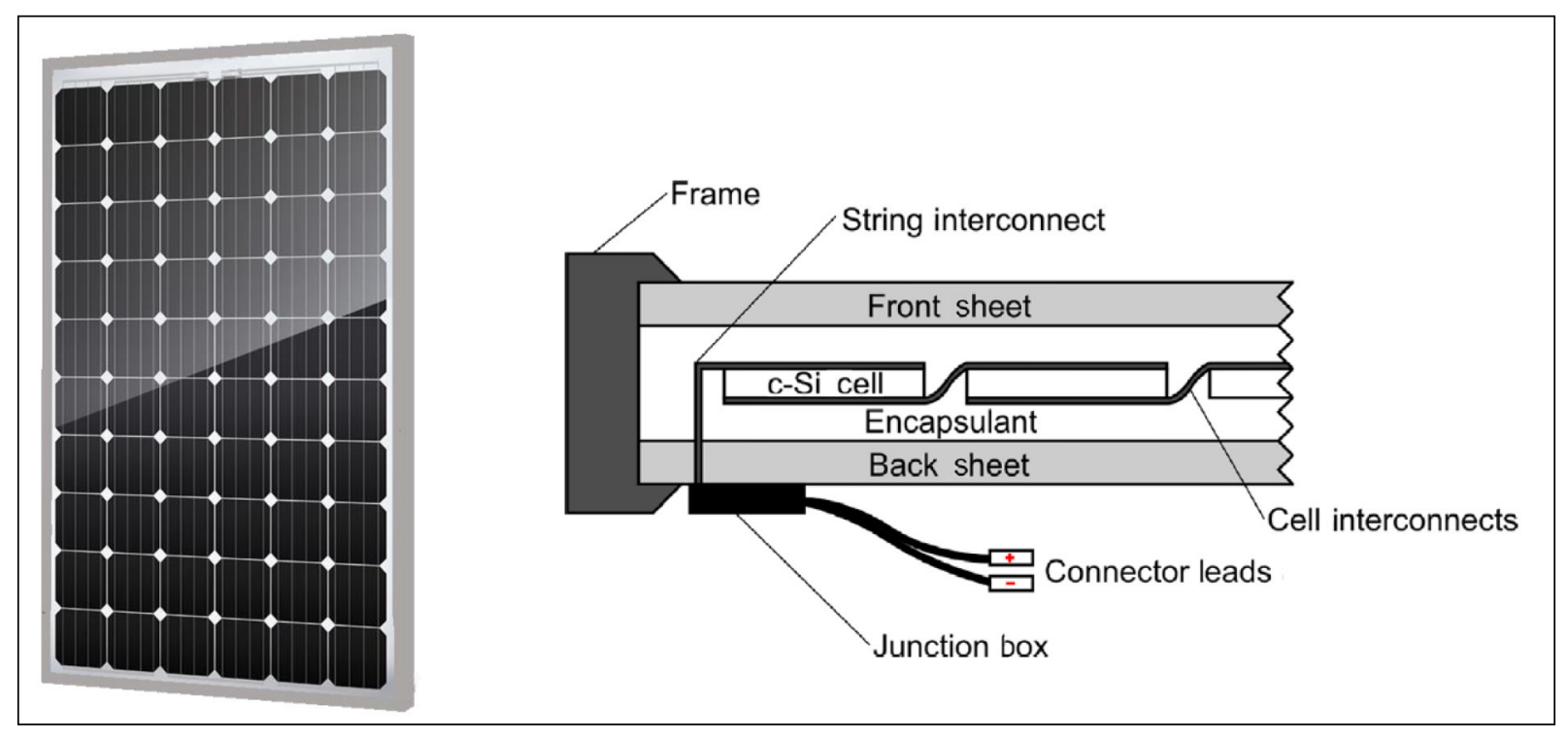

Fig. 1. The front view and cross-section of a typical solar module

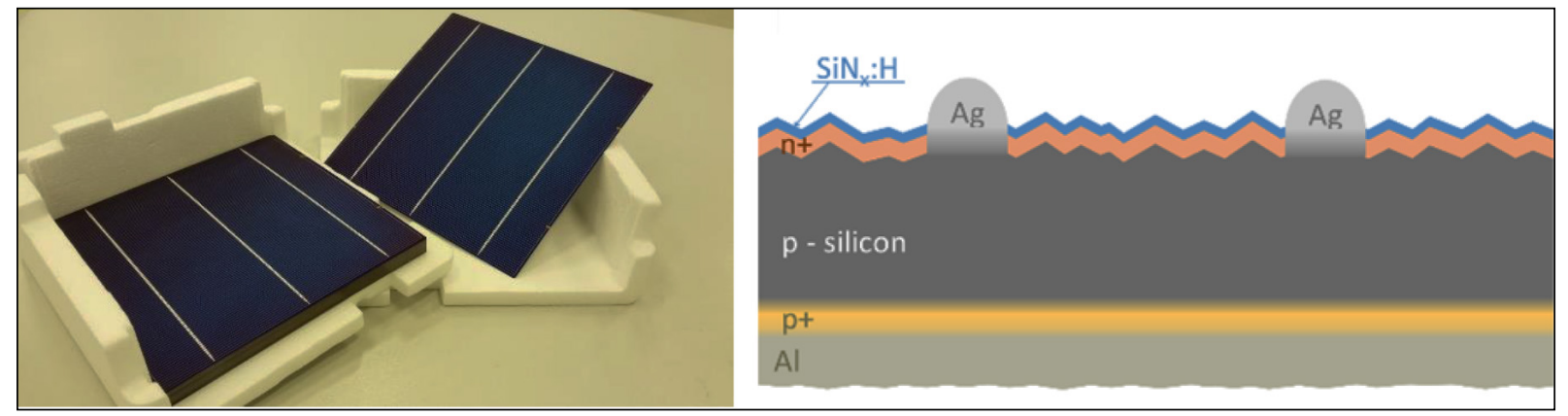

Fig. 2. The front view and cross-section of an AI-BSF type solar cell 
The recycling practices for $\mathrm{PV}$ modules (at the end of service time) can be classified into three types: mechanical, thermal and chemical (leaching and etching) treatment 弱. Mechanical treatment is usually employed as a pretreatment to remove $\mathrm{Al}$ frame followed by crushing or milling of the waste modules into small particles or fine powder 河. After that, chemical leaching using different acids (e.g. $\mathrm{HCl}, \mathrm{H}_{2} \mathrm{SO}_{4}, \mathrm{HNO}_{3}$, etc.) is used to extract $\mathrm{Ag}$ and $\mathrm{Al}[8]$. However, to increase the recovery rate and avoid formation of organic radiuses, mechanical treatment had been replaced by thermal treatment; spent solar modules were heated at $600^{\circ} \mathrm{C}$ to liberate the solar cell from full modules and other organic components, then the chemical treatment was followed [9, 10]. Because the recovered metals (especially $\mathrm{Si}$ ) were contaminated or coated by a SiNx layer, several etching processes using HF and other chemicals were used to remove the SiNx layer [1, 12,

Yousef et all. [13] investigated the feasibilities to recover the same metals by nitric acid $\mathrm{HNO}_{3}$. Firstly, mechanical pretreatment by milling was used to break the chemical and mechanical bonds between the Ag electrodes, $\mathrm{Al}$ electrode, and the Si layer of SCW samples to increase the surface area for reaction. After this, the milled SCW was treated using $\mathrm{HNO}_{3}$ with concentration $>60 \%$ to dissolve $\mathrm{Ag}$ and break the chemical bonds between spherical $\mathrm{Al}$ microparticles in the $\mathrm{Al}$ paste layer. Only a small amount of the $\mathrm{Al}$ was dissolved from the surface of the particles since due to the high concentration of $\mathrm{HNO}_{3}$ passivation of $\mathrm{Al}$ occurred, forming a thin layer from aluminum oxide $\left(\mathrm{Al}_{2} \mathrm{O}_{3}\right)$ that prevented the further dissolution of $\mathrm{Al}$.

The aim of this study was to find the optimal conditions for Si recovering from SCW by use of $\mathrm{HNO}_{3}$.

\section{EXPERIMENTAL}

\section{Preparation of solar cells waste (SCW) for laboratory investigation}

For chemical treatment of SCW (in fact unused solar cells) received from JSC 'SoliTek R\&D' (Fig. 3), in Lithuania, it was decided to perform experiments on milled and crushed solar cells. The samples were grinded by Planetary Ball Mill (PM 100) at $300 \mathrm{rpm}$ for 2 min with 30 s intervals, then for 3 min without an interval. The micro-powder of a total weight of

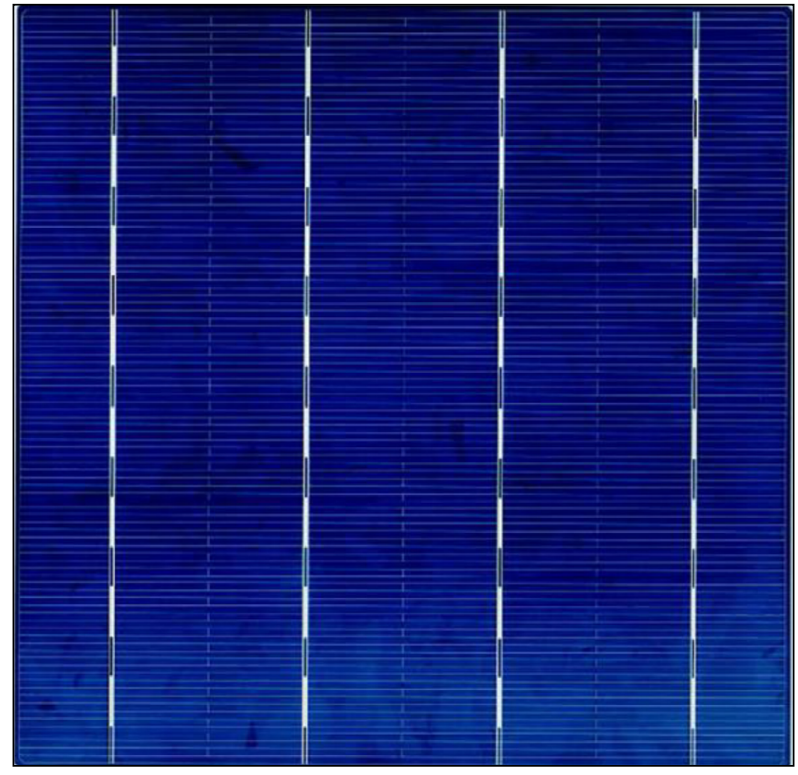

Fig. 3. The investigated unused solar cell before mechanical treatment (JSC'SoliTek R\&D')

$81.82 \mathrm{~g}$ was obtained (Fig. 4). The crushing of solar cell samples was done manually imitating the rejected or damaged solar cell wafers produced while manufacturing (Fig. 5).

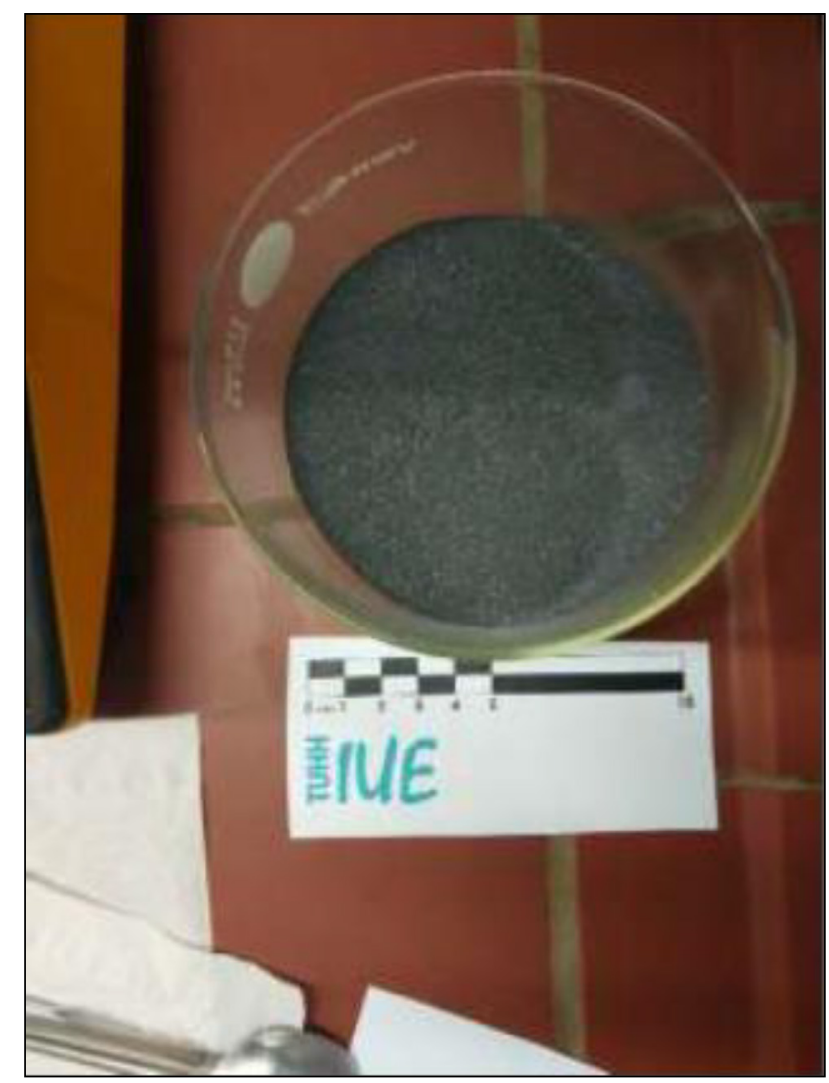

Fig. 4. Micro-powder obtained after milling the solar cell samples 


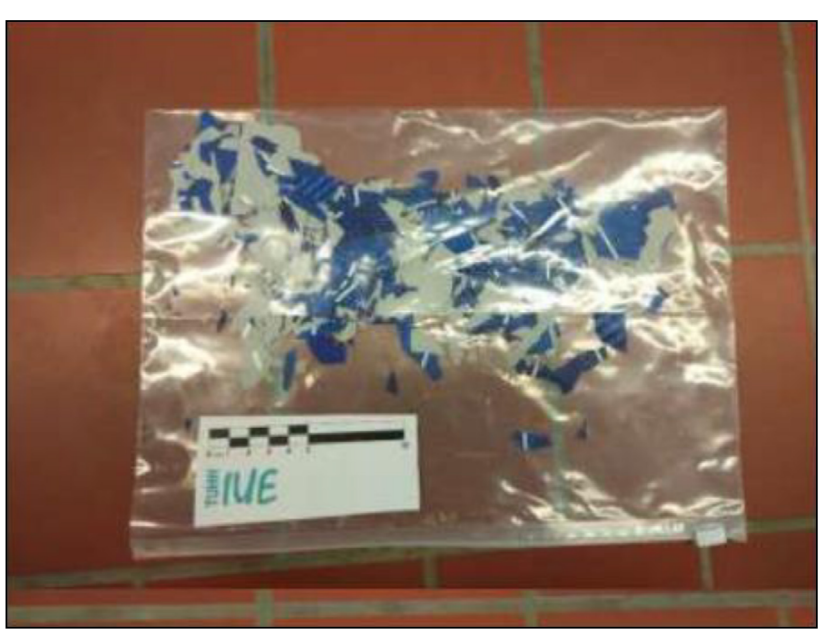

Fig. 5. Crushed solar cell samples

\section{Chemical treatment of crushed and milled SCW samples}

Experiment $A$

About $2 \mathrm{~g}$ of SCW samples (both crushed and milled) were weighed in triplicates and then treated with $50 \mathrm{~mL}$ of nitric acid $\mathrm{HNO}_{3}$ of different molarities: $1,2,3$ and $4 \mathrm{M}$.

\section{Experiment $A 1$}

Solutions with milled solar cells (Fig. 4) were left for $5 \mathrm{~h}$ at the room temperature on a rotary shaker ca. $550 \mathrm{rpm}$. After $5 \mathrm{~h}$ the solutions were filtered. The filters with micro-powder were left overnight, next day weighed and collected for EDX analysis.

\section{Experiment A2}

Solutions with crushed solar cells (Fig. 5) were left overnight at room temperature on the rotary shaker ca. $550 \mathrm{rpm}$. The crushed solar cells were washed with deionized water, dried at $T=105^{\circ} \mathrm{C}$ and packed for EDS analysis.

\section{Experiment $B$}

A similar experimentation with crushed solar cells was repeated by stirring and heating at $50^{\circ} \mathrm{C}$. Treatment continued about $3 \mathrm{~h}$.

The following reactions take place during the chemical treatment process:

$$
\begin{aligned}
& \mathrm{Al}+6 \mathrm{HNO}_{3}=\mathrm{Al}^{3+}+3 \mathrm{NO}_{3}^{-}+3 \mathrm{NO}_{2}+3 \mathrm{H}_{2} \mathrm{O}, \\
& \mathrm{Ag}+2 \mathrm{HNO}_{3}=\mathrm{Ag}^{+}+\mathrm{NO}_{3}^{-}+\mathrm{NO}_{2}+\mathrm{H}_{2} \mathrm{O}
\end{aligned}
$$

The dissolution of metals in nitric acid releases gaseous nitrogen dioxide, which would inevitably create technological and environmental problems during Si recovering.

\section{Analysis of untreated solar cells and treatment} residues: XRD and SEM-EDX measurements

The X-ray diffraction patterns of SCW were recorded with a DRON6 diffractometer in a BraggBrentano configuration. A ZEISS EVO MA10 scanning electron microscope equipped with a Bruker XFlash 6/10 EDS detector was used for chemical composition measurements of solar cell waste treatment residues.

\section{Calculation of $\mathrm{Al}$ and $\mathrm{Ag}$ leaching efficiency from SCW}

The share of metals ( $\mathrm{Al}$ and $\mathrm{Ag}$ ) leached from SCW by $\mathrm{HNO}_{3}$ is calculated as follows:

$$
M e_{\text {leached }}(\%)=\frac{M e_{\text {leached }}(g)}{M e_{\text {previous }}(g)} 100 \% .
$$

Here $M e_{\text {leached }}(\mathrm{g})$ is the mass of leached metal from treated sample and $M e_{\text {previous }}(\mathrm{g})$ is the mass of metal in the SCW sample before treatment.

$M e_{\text {leached }}(\mathrm{g})$ is calculated as follows:

$$
M e_{\text {leached }}(\mathrm{g})=M e_{\text {previous }}(\mathrm{g})-M e_{\text {residual } N}(\mathrm{~g}) .
$$

Here $M e_{\text {residual } N}(\mathrm{~g})$ is the normalized mass of metal in the SCW sample after treatment considering that the content of silicon $\mathrm{Si}$ is not decreased due to the SCW treatment by $\mathrm{HNO}_{3}$; however, the losses of treated SCW during filtration are possible.

$$
\begin{aligned}
& M e_{\text {residual } N}(\mathrm{~g}) \text { is calculated as follows: } \\
& M e_{\text {residual } N}(g)=\frac{S i_{\text {previous }}(g) \cdot M e_{\text {residual }}(g)}{S i_{\text {residual }}(g)} .
\end{aligned}
$$

Here $M e_{\text {residual }}(\mathrm{g})$ is the mass of residual metal in the treated SCW sample, $S_{\text {residual }}(\mathrm{g})$ is the mass of residual silicon in the treated SCW sample, considering that the losses of Si are possible only in the filtration process but not during chemical treatment by $\mathrm{HNO}_{3}$, and $S i_{\text {previous }}(\mathrm{g})$ is the mass of silicon in the SCW sample before treatment.

$\mathrm{Me}$ and Si masses in the samples both before treatment and after it are calculated according to the EDX measure data

$$
M e(\mathrm{~g})=m_{\text {sample }} \cdot \operatorname{Me}(\%) / 100,
$$




$$
\operatorname{Si}(\mathrm{g})=m_{\text {sample }} \cdot \operatorname{Si}(\%) / 100,
$$

where $\mathrm{Me}(\%)$ and $\mathrm{Si}(\%)$ are by the EDS method measured $\mathrm{Me}$ and $\mathrm{Si}$ contents in the samples before and after treatment.

\section{RESULTS AND DISCUSSION}

\section{Elemental composition of untreated SCW}

At the beginning, the primary content of investigated SCW has been evaluated by the XRD method (Fig. 6). The XRD spectrum is undoubtedly dominated by silicon peaks (violet colour online) and aluminum peaks (blue colour online) that are visible. Trace amounts of quartz $\mathrm{SiO}_{2}$ (very small green peaks online) were recorded as a product of slight oxidation of silicon. Minor Ag peaks (red colour online) are also weekly observable.

In Figs. 7 and 8, the SEM images and EDS spectrums of untreated SCW are presented. Fig. 9 is provided for milled SCW subsequently treated at $20^{\circ} \mathrm{C}$ (Experimentation A), and Fig. 10 is provided for crushed SCW subsequently treated at $50^{\circ} \mathrm{C}$ (Experimentation B). For the crushed sample the average size of SCW particles is $200-500 \mu \mathrm{m}$, for the milled one it is $10-50 \mu \mathrm{m}$. In both cases, comparisons of the established $\mathrm{Si}$, $\mathrm{Al}$ and $\mathrm{Ag}$ content are given in the Table, where the content of impurities consisting mainly of carbon $\mathrm{C}$ and oxygen $\mathrm{O}$ is also shown. It is also visible in both EDS spectra. Nitrogen $\mathrm{N}$ and $\mathrm{F}$

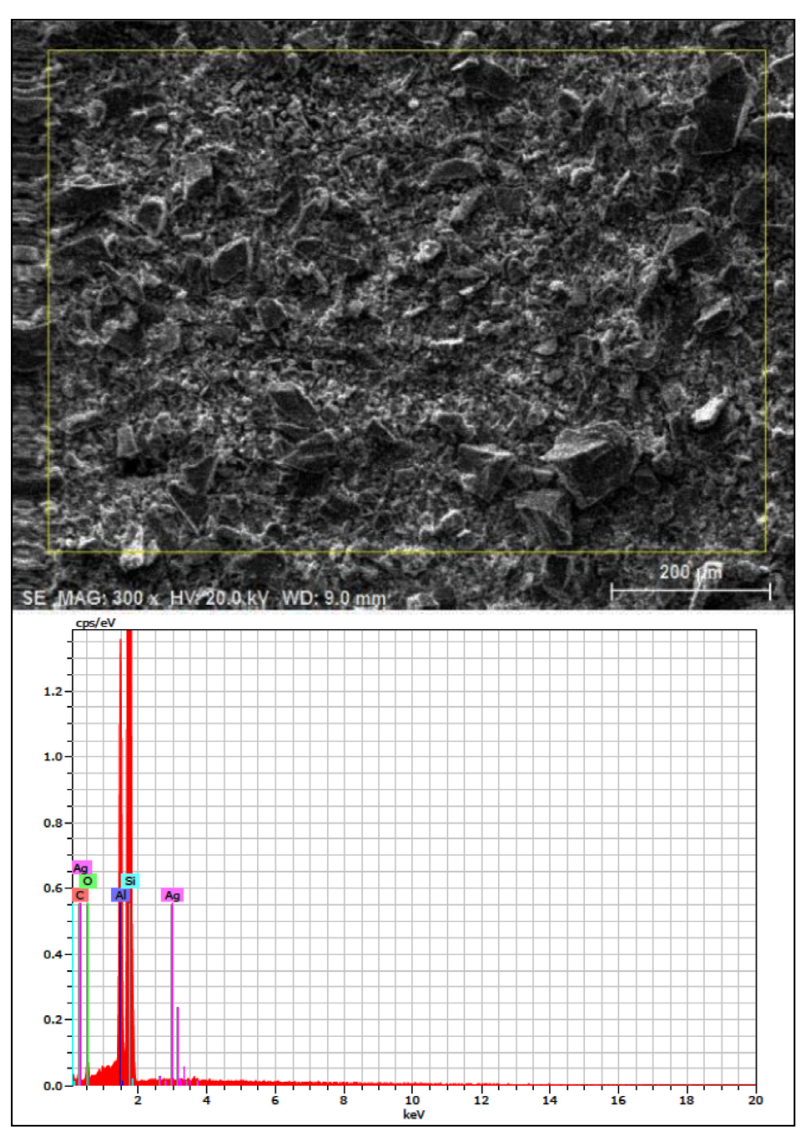

Fig. 7. The SEM image and EDS spectrum for milled SCW before treatment by nitric acid at $20^{\circ} \mathrm{C}$

are also observed in the EDS spectrum shown in Fig. 10. The reason for their presence is the treatment of silicon wafers with $\mathrm{HNO}_{3}$ - $\mathrm{HF}$ mixture during the production of solar cells.

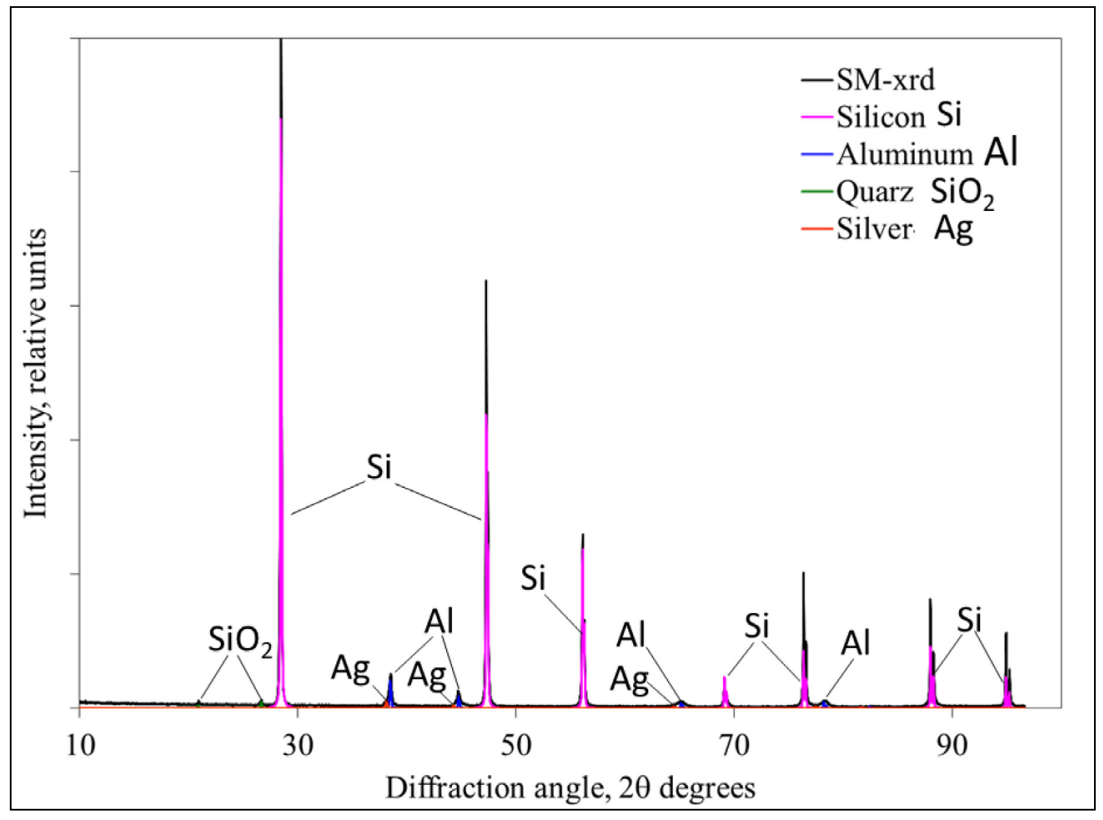

Fig. 6. XRD spectrum of SCW 

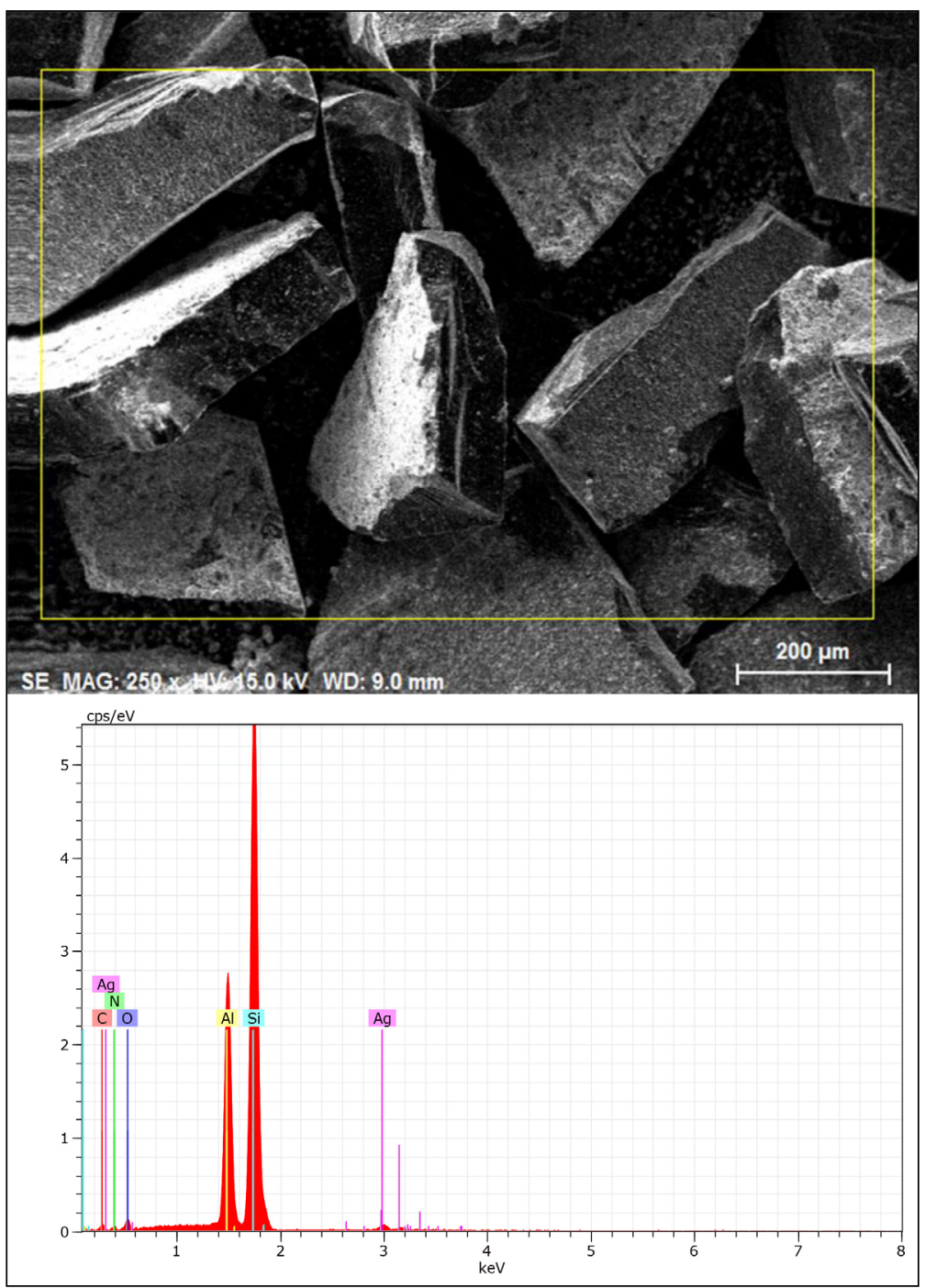

Fig. 8. The SEM image and EDS spectrum for crushed SCW before treatment by nitric acid at $50^{\circ} \mathrm{C}$

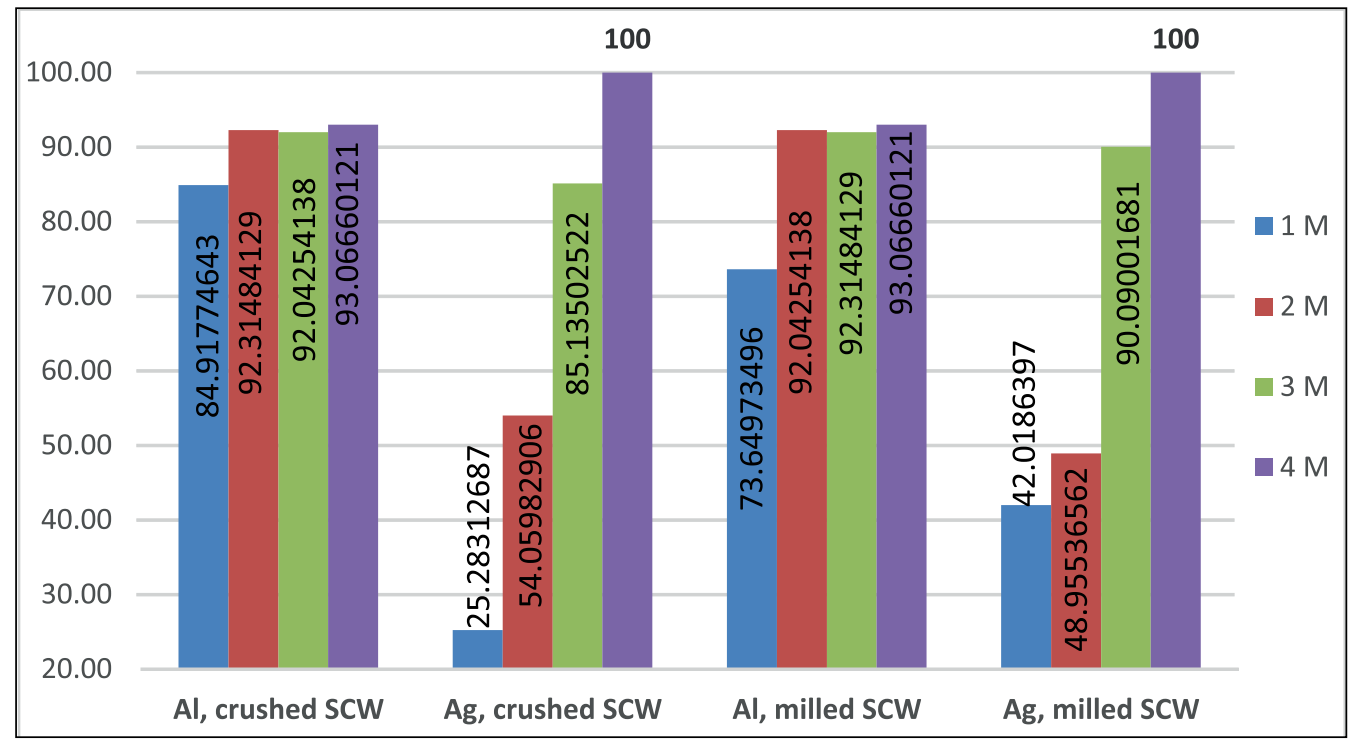

Fig. 9. Percentages of $\mathrm{Ag}$ and Al leached by $1,2,3$ and $4 \mathrm{M} \mathrm{HNO}_{3}$ from SCW in two different forms $\left(t=20^{\circ} \mathrm{C}\right)$ 


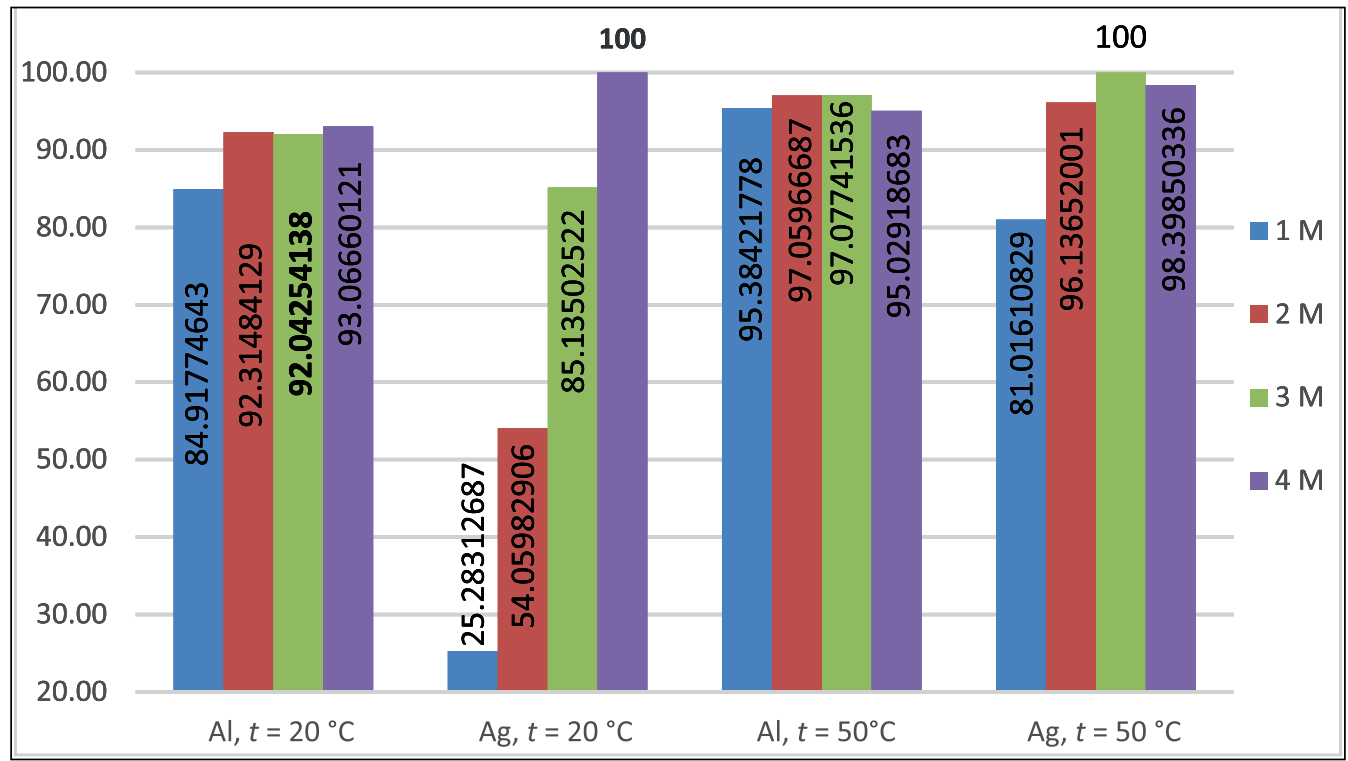

Fig. 10. Percentages of $\mathrm{Ag}$ and $\mathrm{Al}$ leached by $1,2,3$ and $4 \mathrm{M} \mathrm{HNO}_{3}$ from crushed $\mathrm{SCW}$ at 20 and $50^{\circ} \mathrm{C}$ temperatures

Table. The weight and elemental content of $\mathrm{SCW}$ samples before and after treatment by $\mathrm{HNO}_{3}$

\begin{tabular}{|c|c|c|c|c|c|c|}
\hline 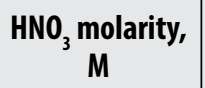 & $\begin{array}{c}\text { Common mass } \\
\text { of untreated samples, } g\end{array}$ & $\begin{array}{c}\text { Common mass } \\
\text { of treated samples, } g\end{array}$ & Si content, $\%$ & Al content, $\%$ & Ag content, $\%$ & $\begin{array}{l}\text { Admixture } \\
\text { content, } \%\end{array}$ \\
\hline \multicolumn{7}{|c|}{ Experimentation A1: milled SCW $t=20^{\circ} \mathrm{C}$} \\
\hline \multicolumn{3}{|c|}{ Untreated sample } & 73.10 & 10.76 & 0.09 & 16.05 \\
\hline 1 & 6.0124 & 5.0216 & 84.05 & 3.26 & 0.06 & 12.63 \\
\hline 2 & 6.0074 & 4.9224 & 79.56 & 0.90 & 0.05 & 19.49 \\
\hline 3 & 6.0038 & 4.6872 & 81.96 & 0.96 & 0.01 & 17.07 \\
\hline 4 & 6.0085 & 4.9069 & 64.67 & 0.66 & 0.00 & 34.67 \\
\hline \multicolumn{7}{|c|}{ Experimentation A2: crushed SCW, $t=20^{\circ} \mathrm{C}$} \\
\hline \multicolumn{3}{|c|}{ Untreated sample } & 73.10 & 10.76 & 0.09 & 16.05 \\
\hline 1 & 6.0209 & 5.4336 & 81.53 & 1.81 & 0.05 & 16.61 \\
\hline 2 & 6.0161 & 4.7735 & 79.56 & 0.90 & 0.03 & 19.51 \\
\hline 3 & 6.0195 & 5.3192 & 81.96 & 0.96 & 0.01 & 17.07 \\
\hline 4 & 6.0177 & 5.2023 & 64.67 & 0.66 & 0.00 & 34.67 \\
\hline \multicolumn{7}{|c|}{ Experimentation $\mathrm{B}$ : crushed $\mathrm{SCW}, t=50^{\circ} \mathrm{C}$} \\
\hline \multicolumn{3}{|c|}{ Untreated sample } & 61.99 & 18,9 & 3.48 & 15.63 \\
\hline 1 & 6.0006 & 4.9761 & 73.19 & 1.03 & 0.78 & 25.00 \\
\hline 2 & 6.0114 & 4.4292 & 69.16 & 0.62 & 0.15 & 30.07 \\
\hline 3 & 6.0372 & 4.7154 & 69.58 & 0.62 & 0.00 & 29.80 \\
\hline 4 & 6.0744 & 4.9443 & 77.86 & 1.18 & 0.07 & 20.89 \\
\hline
\end{tabular}

The Ag content for experimentation $\mathrm{A}$ is about 58 times lower than for experimentation B. This can be explained that these two experimentations have been performed in different times and different parties of SCW have been got from JSC 'SoliTek R\&D'. However, such differences among Ag contents do not play the negative role for assessment of Ag leaching efficiency, as we shall see later.

\section{Filtering characteristics of treated SCW and} weight losses

After the SCW treatment by nitric acid, the filtration process for crushed and milled solar cells proceeded relatively quickly. However, with crushed samples the filtration process is faster. With milled solar cells, there were some difficulties with filtration. Because it was challenging to collect all 
powder from the bottles, all the particles of the solar cells were collected in bottles with water after the acid had been drained.

As it can be seen from the Table, the losses with milled solar cells are significant.

\section{Investigation of SCW leaching residues}

Table 1 represents the results of weight of all samples before and after treatment (leaching tests), also the $\mathrm{Si}, \mathrm{Al}$ and $\mathrm{Ag}$ content in all treated samples, measured by the EDS method. Significant visual changes of SEM-EDS images for the SCW samples after treatment are not observed.

According to formulas 3-7 calculated leaching efficiencies of $\mathrm{Al}$ and $\mathrm{Ag}$ from SCW are presented in Figs. $9-10$.

At $20^{\circ} \mathrm{C}$, the leaching of $\mathrm{Al}$ from the crushed SCW is stabilized as early as the concentration of $2 \mathrm{M}$ nitric acid $\mathrm{HNO}_{3}$, and with increasing of $\mathrm{HNO}_{3}$ molarity Al leaching remains similar - about $93 \%$. A similar trend is characteristic of milled SCW, but at $1 \mathrm{M} \mathrm{HNO}_{3}$ the leaching of $\mathrm{Al}$ is about $73 \%$, i.e. for $11 \%$ lower that for crushed SCW. It means that for fine SCW particles, reagent access to them is reduced. The absence of complete $\mathrm{Al}$ leaching can be explained by the fact that the Al particles in SCW are relatively large and that their complete dissolution is partially blocked by the formation of an aluminum oxide $\mathrm{Al}_{2} \mathrm{O}_{3}$ layer on their surface, also due to possible forming $\mathrm{Al}-\mathrm{Si}$ compounds [8]. As the nitric acid concentration increases, Ag leaching increases with a virtually linear dependence for both crushed and milled SCW and becomes complete at $4 \mathrm{M}$. On the lower $\mathrm{HNO}_{3}$ molarity Ag leaching efficiency is noticeably higher for milled SCW (Fig. 9).

Evaluating the influence of temperature on leaching of $\mathrm{Al}$ and $\mathrm{Ag}$, we can see that $\mathrm{Al}$ leaching at $50^{\circ} \mathrm{C}$ in the $1-4 \mathrm{M} \mathrm{HNO}_{3}$ concentration range is practically smooth with a similar leaching limit as at $20^{\circ} \mathrm{C}$ with a higher $\mathrm{HNO}_{3}$ molarity. It can be explained by the fact that, for conditional large $\mathrm{Al}$ particles, at higher temperatures under higher diffusion conditions the role of $\mathrm{HNO}_{3}$ amount is not essential in this concentration range. Also, the Ag leaching differences at different $\mathrm{HNO}_{3}$ concentrations are drastically reduced as the leaching temperature rises (Fig. 10).

\section{SUMMARY AND CONCLUSIONS}

1. The investigations have been carried out to determine the feasibility of silicon ( $\mathrm{Si}$ ) recovering from solar cell waste (SCW) by chemically removing aluminium (Al) and silver ( $\mathrm{Ag}$ ) from silicon matrix, using nitric acid $\left(\mathrm{HNO}_{3}\right)$ of various molarities as an active oxidant. The initial $\mathrm{Al}$ content in SCW ranged from 11 to $19 \%$, and that of silver from 0.1 to $3.5 \%$.

2. Initially, during the SCW treatment with nitric acid at $20^{\circ} \mathrm{C}$, it becomes clear that the $\mathrm{Al}$ and $\mathrm{Ag}$ removal process is more efficient on larger SCW particles due to the spatially caused conditions for penetration of the acid ions. When the nitric acid concentration increases, the maximal leaching $(93 \%)$ of $\mathrm{Al}$ is already achieved at $2 \mathrm{M} \mathrm{HNO}_{3}$. The absence of complete $\mathrm{Al}$ leaching can be explained by the fact that the Al particles in SCW are relatively large and that their complete dissolution is partially blocked by the formation of an aluminum oxide $\mathrm{Al}_{2} \mathrm{O}_{3}$ layer on their surface, also due to possible forming $\mathrm{Al}-\mathrm{Si}$ compounds. Meanwhile, at $20^{\circ} \mathrm{C}, \mathrm{Ag}$ leaching efficiency increases almost linearly with increasing $\mathrm{HNO}_{3}$ concentration and it becomes $100 \%$ at $4 \mathrm{M}$.

3. At $50^{\circ} \mathrm{C} \mathrm{HNO}_{3}$ concentration (in a range of 1-4 M) the latter no longer influences the leaching of $\mathrm{Al}$ - its efficiency ranges from 95 to $97 \%$, thus achieving the same leaching maximum. And the slope of Ag linear leaching efficiency dependence on the $\mathrm{HNO}_{3}$ concentration is significantly lower at higher temperature.

4. Optimal concentrations for removal of $\mathrm{Ag}$ and $\mathrm{Al}$ and recovering of $\mathrm{Si}$ are 2 and $3 \mathrm{M}$ nitric acid $\left(\mathrm{HNO}_{3}\right)$, respectively.

\section{ACKNOWLEDGEMENTS}

This research was particularly performed in the framework of scientific project 'SCW to VM', funded by Baltic-Germany University Liaison Office in 2019. Also the authors of this article are thankful to JSC 'SoliTek R\&D' (Vilnius, Lithuania) for support of the investigated material and to colleagues from the Laboratory of Materials Research and Testing (Lithuanian Energetic Institute, Kaunas, Lithuania) for their support in the XRD and SEM-EDS analysis of SCW composition. 


\section{References}

1. D. Feldman, R. Margolis, Q42018/Q1 2019 Solar Industry Update (2019).

2. ITRPV Roadmap for Photovoltaics (2018).

3. End-of-life Management: Solar Photovoltaic Panels [www.irena.org].

4. K. O. Davis, M. P. Rodgers, G. Scardera, et al., Renew. Sustain. Energy Rev., 59, 225-252 (2016).

5. Products and Services [www.solitek.eu].

6. E. J. Schneller, R. P. Brooker, N. S. Shiradkar, et al., Renew. Sustain. Energy Rev., 59, 992-1016 (2016).

7. Y. Xu, J. Li, Q. Tan, A. L. Peters, C. Yang, Waste Manag., 75, 450-458 (2018).

8. Y. K. Yi, H. S. Kim, T. Tran, S. K. Hong, M. J. Kim, J. Air Waste Manag. Assoc., 64, 797-807 (2014).

9. E. Klugmann-Radziemska, P. Ostrowski, K. Drabczyk, P. Panek, M. Szkodo, Sol. Energy Mater. Sol. Cells, 94, 2275-2282 (2010).

10. M. Tammaro, J. Rimauro, V. Fiandra, A. Salluzzo, Renew. Energy, 81, 103-112 (2015).

11. J. Shin, J. Park, N. Park, Sol. Energy Mater. Sol. Cells, 162, 1-6 (2017).

12. W. H. Huang, W. J. Shin, L. Wang, W. C. Sun, M. Tao, Sol. Energy, 144, 22-31 (2017).

13. S. Yousef, M. Tatariants, J. Denafas, V. Makarevicius, S. I. Lukosiute, J. Kruopiene. Sol. Energy Mater. Sol. Cells, 191, 493-501 (2018).
Agnè Šleiniūtė, Liucija Urbelytė, Julius Denafas, Arina Kosheleva, Gintaras Denafas

SILICIO ATGAVIMO IŠ SAULĖS CELIŲ ATLIEKUৃ APDOROJANT AZOTO RÜGŠTIMI GALIMYBE்S

Santrauka

Ištirtos silicio atgavimo iš Saulès celių atliekų (SCA) apdorojant azoto rūgštimi galimybės $1 \mathrm{M}, 2 \mathrm{M}, 3 \mathrm{M}$ ir $4 \mathrm{M}$ koncentracijuc sąlygomis. Tyrimu rezultatai parodè, kad visiškas aliuminio pašalinimas iš silicio matricos nèra imanomas, nes ant aliuminio dalelių susidaro aliuminio junginiai su deguonimi ir siliciu. Visiškas sidabro pašalinimas pasiekiamas esant didžiausiai $4 \mathrm{M}$ azoto rūgšties koncentracijai. Azoto rūgšties koncentracijų ịtaka minètų metalų pašalinimo efektyvumui aukštesnès (iki $50{ }^{\circ} \mathrm{C}$ ) temperatūros sąlygomis pastebimai mažeja. Didesnis metalų pašalinimo efektyvumas yra būdingas esant didesnèms SCA dalelèms, kai susidaro palankesnès sąlygos azoto rūgšties jonų migracijai. 